\title{
Explaining \\ Relationships Among \\ Student Outcomes \\ and the School's \\ Physical Environment
}

\author{
C. Kenneth Tanner \\ The University of Georgia
}

Many people believe that educational facilities are just big boxes in which learning occurs, places to store students until they drop out of school or graduate. Unfortunately, many educational decision-makers, teachers, school board members, parents, and architects feel that the design of these boxes, usually with a long and often dark, center corridor, has little to add to the process of learning. Given the great variance in school structures, it is not surprising that the physical environment of schools in the United States is in peril, as emphasized by the National Center for Educational Statistics (NCES; 2000, 2003, 2007). Even a new school building may have problems such as inadequate natural light, circulation and movement patterns, meeting spaces, and instructional places. Older buildings frequently face agerelated issues such as poor color schemes and inefficient energy systems that can lead to uncomfortable indoor climate and high utility bills. With issues of this magnitude as supporting evidence, this study is based on the hypothesis that the substandard condition of facilities and, in particular, the inappropriateness of 
This descriptive study investigated the possible effects of selected school design patterns on third-grade students' academic achievement. A reduced regression analysis revealed the effects of school design components (patterns) on ITBS achievement data, after including control variables, for a sample of third-grade students drawn from 24 elementary schools. The sample means on the ITBS per school represented approximately 1,916 third-grade students. The independent variable set for developing a possible explanation of student achievement was the school's physical environment, defined as four sets of design patterns: movement and circulation (e.g., adequate personal space and efficient movement patterns throughout the school), large group meeting places (e.g., social gathering places), day lighting and views (e.g., windows with natural light), and instructional neighborhoods (e.g., large and small group areas that accommodate wet and dry activities). Each of the four full regression models, which included subsets of the design elements, explained between $2 \%$ and $7 \%$ of additional variance in achievement when compared to the reduced model, which included a measure of school SES. Therefore, each of the four design variables was positively related to student achievement, even after controlling for school SES. 
school design may influence student achievement negatively. The NCES (2000) reported that about one fourth of the schools in the United States were in less than adequate condition. Fortythree percent of the schools in the NCES (2000) study were rated as unsatisfactory in at least one of the following environmental design areas: lighting, heating, ventilation, indoor air quality, noise control, and security. In a recent study, 30\% of public schools reported that they were overenrolled (NCES, 2007), giving credence to the study of movement within and around learning environments.

Although the NCES studies are valuable in characterizing physical conditions and describing the schools as boxes with mechanical problems, they did not compare student achievement to the design of the physical environment. Therefore, it is timely to challenge the notion that educational facilities are only big, and often ugly, mechanical boxes having a questionable or unknown amount of variance to add to the process of student learning. With these parameters offering some specific gaps in knowledge about the impact of the physical environment on student outcomes, three relative assumptions guided this study:

- Educational facilities should be viewed as a collection of environments that influence learning.

- The physical environment influences student attitudes and behavior.

- Where students learn is as important as many aspects of the curriculum.

\section{Statement of the Problem}

Because there are limited research-based measurements indicating to what degree the school's physical environment contributes to or influences a student's cognitive learning, this study investigated a group of school design variables that could possibly influence student outcomes. A major issue was that many school environments have been hastily constructed on whims of community leaders seeking quick solutions to student 
population explosions. Furthermore, educational environments have sometimes been copied from existing failing structures, while others have been built according to so called best practices broadly defined by planners, educators, and architects. The issues associated with hearsay evidence, repetitive school design, and best practices have gone unchallenged, igniting questions such as why replicate, or which best practices do we select? Design elements compatible with teaching and learning philosophies may not have been taken into account. Exactly how does the school's physical environment influence various educational and cultural settings?

\section{Purpose}

The purpose of this study was to quantify four sets of design patterns (movement and circulation, large group meeting places, day lighting and views, and instructional neighborhoods) in the school's physical environment and analyze how they might relate to the academic achievement of students. Design patterns as employed in this study refer to a school's structural and movable architectural components and natural components that are akin to the patterns as defined by Alexander, Ishikawa, and Silverstein (1977). The background for this work was described by Alexander (1979) in a volume devoted to influencing a new attitude toward architecture and planning - an alternative intended to enhance or possibly replace unsound ideas and practices.

Design patterns describe and explain the relationships among aspects of the physical environment and learning goals. They summarize the linkages among the creation of structures and the embellishment of those structures relevant to a particular project objective. Therefore, design patterns support a language for communicating a base map for planning and design that allows for choices that are useful to the goals of the project (in our present discussion, an educational facility that influences student outcomes). 
Academic achievement was limited to measures of thirdgrade mean composite scores on the Iowa Tests of Basic Skills (ITBS) from a sample of 24 schools. The ITBS is based on norms that allow standardized comparisons among groups of students and schools.

\section{Basic Assumptions}

An underlying assumption for this study was that the design patterns of the school's physical environment influence student achievement, paralleling the supposition that schools should be viewed as comprehensive learning environments and not just boxes where students hang out until they graduate or drop out of school. Another assumption was that the philosophy of teaching and the philosophy of learning dictate spaces for learning. The third assumption was that learning styles and teaching styles reflect the cultural and community contexts. Without question, the philosophy and curriculum should dictate all the structural and movable components of the architectural and natural learning support systems, and each school should clearly reflect the community's context and values.

Paralleling the assumption that the philosophy of teaching and philosophy of learning dictate spaces where these activities occur was a premise that student learning and teaching take place somewhere on a continuum between skill-based and constructivist theories. Skill-based theories are often associated with Skinner (1957) and Watson (1928). This approach assumes that learning is "teacher-centered." Students sit, listen, and practice a task until performance is perfected. They memorize facts for a test. The teacher does most of the work. Constructivist theories are linked to individuals such as Piaget (1924) and Montessori (1967). "Learning by doing" describes the larger part of this theory. This perspective also may be known as project-based learning, where students work in teams to explore real-world problems and create presentations to share what they have learned. Students do most of the work under this theory. 


\section{Defining the Physical Environment}

A few studies of the physical environment and student outcomes have been conducted (Earthman \& Lemasters, 1998; Lemasters, 1997; Tanner, 2000, 2006; Wohlwill \& vanVliet, 1985; Yarborough, 2001). With sporadic and often inconclusive information existing in the literature concerning the effects that the physical environment has upon students, there exists a need for current, valid, and reliable data to support or refute the perspectives underlying this inquiry. If consistent relationships can be found between school design patterns and student achievement, then architects, school system personnel, educators, and policy makers could employ this information to make scientifically informed decisions regarding the future design of school environments. The results could be optimal learning environments. If no significant relationships are found, then the theoretical perspective may be weakened. The following sections present an overview of the variable clusters that this study investigated.

\section{Movement and Circulation Classifications}

Movement patterns are described in this study as links to main entrances, pathways with goals, circulation classifications, density or freedom of movement, personal space, and social distance. These movement patterns have been of interest to researchers in the field of environmental psychology and architecture for many years. In the 20th century, Alexander et al. (1977) and Sommer (1969) made significant contributions to this field. Sommer focused on personal and social distance and Alexander et al. dealt with comprehensive design classifications and their relationships to people, towns, regions, and the global environment.

A crowded school, ignoring personal and social distance, has a negative influence on student outcomes. Thus,

It appears as though the consequences of high-density conditions that involve either too many children or too 
little space are: excess levels of stimulation; stress and arousal; a drain on resources available; considerable interference; reductions in desired privacy levels; and loss of control. (Wohlwill \& van Vliet, 1985, p. 108)

The issue of density may be viewed through psychological implications by studying territoriality of place (Banghart \& Trull, 1973). Because the school is a social system within the cultural environment, social distance as it relates to crowding and density is a function of school design and decision-making. Another aspect of density is the lower middle range for social distance for men and women, which is 7 feet (Banghart \& Trull, 1973, p. 233). Sommer (1969) completed several studies on small-group ecology and found that when people are at 3.5 feet apart, they shift their seating positions in favor of "side by side" as opposed to "across" from each other (p. 66). Seven feet appears to be the maximum diameter for social distance. Sommer's finding correlates with the 7 feet $(2 \times 3.5$ feet $)$ needed for social distance for men and women as recommended by Banghart and Trull (1973).

The architectural design of student circulation space has an obvious influence on the educational function of a school building (Castaldi, 1994). Space in a room delivers a silent message to students, where the flow and shift of distance between people is a large part of the communication process (Duncanson, 2003; Hall, 1959). Special attention should be given to circulation classifications that permit student traffic to flow quickly from one part of the building to another. Movement within the school should not consist of a progression of individual experiences but instead be a conscious and perceptible environmental exchange, and complex structures that cause crowding should be avoided. Movement within a school may be an important supporter of learning. Pathways free of obtrusions between activity areas and classrooms improve utilization of learning spaces. From this brief review of the literature and combined with the extended work in the University of Georgia's School Design and Planning Laboratory, 17 design elements were identified relative 
to movement and circulation. Numerous design classifications have been developed and tested as part of an original instrument for assessing movement in the schools. Table 1 identifies four classifications selected for review in this study: movement and circulation (17 elements), large group meeting places (5 elements), day lighting and views (5 elements), and instructional neighborhoods (16 elements).

\section{Large Group Meeting Places}

There is a growing awareness of the importance of social areas in schools, going beyond the traditional requirements of rooms in which pupils and teachers can meet and eat. This stems from the perception that an overall atmosphere needs to be created in which pupils can identify and establish a sense of ownership of the environments in which they study and play. Social space should provide places for quiet contemplation and for formal and informal play. Several places are needed, both inside and outside the school, where children can meet together in groups. Such spaces need the characteristics that provide a welcome atmosphere and promote a feeling of belonging (Colven, 1990).

Needs for large group meeting places seem to reflect the community and culture in which the school is located (Crumpacker, 1995). In urban, densely populated areas, people like to find a place to get away from others. In a rural area, people view school as a place to meet and gather and are less likely to want places for privacy.

Simmel, Frisby, and Featherstone (1997) noted that all social interactions could be characterized by their relative degree of proximity and distance among individuals and groups. The increase in physical proximity (personal space) can lead to emotional extremes. When measuring the personal space required by undergraduate students, Cochran, Hale, and Hissam (1984) discovered the limits of one's comfort zone. Their study revealed that interpersonal closeness generates less discomfort in open spaces, which indicates the need to include larger commons indoor spaces and outdoor learning areas in school designs. Public places 


\section{Table 1}

\section{Four Components of the Design Appraisal Scale for Elementary Schools}

\begin{tabular}{|c|c|}
\hline \multirow{2}{*}{\multicolumn{2}{|c|}{$\begin{array}{l}\text { Item } \\
\text { I. Movement and Circulation Classifications }\end{array}$}} \\
\hline & \\
\hline \multicolumn{2}{|l|}{$\begin{array}{l}\text { The school's design may be judged regarding its ability to enable students and teachers to } \\
\text { enter and move freely within and around a facility. }\end{array}$} \\
\hline 1. Promenade ${ }^{* *}$ & Ambiguous --- Distinct \\
\hline \multicolumn{2}{|l|}{$\begin{array}{l}\text { Outside walkways linking main areas; ideally placing major activity centers at } \\
\text { the extremes. }\end{array}$} \\
\hline 2. Pathways*** & Ambiguous --- Clear \\
\hline \multicolumn{2}{|l|}{$\begin{array}{l}\text { Clear and comfortable pathways allow freedom of movement and orientation } \\
\text { among structures. }\end{array}$} \\
\hline \multicolumn{2}{|l|}{ Circulation Classifications } \\
\hline \multicolumn{2}{|l|}{$\begin{array}{l}\text { Indoor spaces for circulation (especially classroom spaces). The passages should be } \\
\text { broad and well-lit, allowing for freedom of movement. }\end{array}$} \\
\hline 3. Within Learning Environments & Poor --- Excellent \\
\hline 4. Hallways and Passageways & Meager Space --- Ample \\
\hline $\begin{array}{l}\text { Allowing students personal space when moving within the school. (Ample } \\
\text { spaces = noncrowded) }\end{array}$ & Space \\
\hline 5. Supervisable Circulation Spaces & Percentage of \\
\hline $\begin{array}{l}\text { (Percentage of supervisable circulation spaces: } 0=0 \%, 1=10 \%, \ldots, 10 \\
=100 \%)\end{array}$ & $\begin{array}{l}\text { Supervisable Circulation } \\
\text { Spaces }\end{array}$ \\
\hline 6. Egress** & None --- Ample \\
\hline \multicolumn{2}{|l|}{$\begin{array}{l}\text { Exits from the building. The best situations allow students to exit (to the out- } \\
\text { side) directly from their classrooms. }\end{array}$} \\
\hline 7. Classrooms*** & Lacking --- Extensive \\
\hline \multicolumn{2}{|l|}{ Exterior doors lead to a courtyard or garden area. } \\
\hline Spaces for Physically Challenged Students & \\
\hline 8. Access to Classrooms & Limited --- Unlimited \\
\hline 9. Access to Hallways & Limited --- Unlimited \\
\hline 10. Access to Lunchroom & Limited --- Unlimited \\
\hline 11. Access to Gymnasium*** & Limited --- Unlimited \\
\hline 12. Access to School Buildings & Limited --- Unlimited \\
\hline 13. Access to Toilets & Limited --- Unlimited \\
\hline 14. Access to Drinking Fountains & Limited --- Unlimited \\
\hline 15. Access to Computer Stations & Limited --- Unlimited \\
\hline 16. Access to School Grounds & Limited --- Unlimited \\
\hline 17. Access to Living Center (Teaching Center)** & Limited --- Unlimited \\
\hline
\end{tabular}

II. Large Group Meeting Places

Public Areas

Spaces fostering a sense of community (unity and belonging). Inviting and comfortable settings including ample lighting.

18. Auditorium**

Poor --- Excellent

19. Amphitheater

Poor --- Excellent

20. Media Center

Poor --- Excellent

21. Commons**

Poor --- Excellent

22. Dining Areas**

Poor --- Excellent

III. Day Lighting and Views

Windows - Spaces bringing natural light into the learning environment.

Windows may have some form of glare control, but should be in use (when glare is not a problem), and be without painted obstructions and other devices restricting views. Windows should invite the outdoors inside. 


\begin{tabular}{|c|c|}
\hline Item & Scale \\
\hline 23. Views Overlooking Life ${ }^{* *}$ & None --- Numerous \\
\hline 24. Unrestricted Views & Sparse --- Ample \\
\hline (when glare/curtains is/are not a problem) & \\
\hline 25. Adequacy of Natural Light** & No Mixture of Lighting \\
\hline (includes skylights and borrowed light-natural, reflected light) & --- Ample Mixture \\
\hline 26. Living Views*** & Inadequate --- Adequate \\
\hline $\begin{array}{l}\text { Vierws of indoor and outdoor spaces (gardens, animals, fountains, mountains, } \\
\text { people, etc.) }\end{array}$ & \\
\hline 27. Natural Light/ Full Spectrum** & No Mixture of Light --- \\
\hline $\begin{array}{l}\text { Artificial light plus natural light from the outside, preferably on two sides of } \\
\text { every room. }\end{array}$ & Ample Mixture \\
\hline \multirow{2}{*}{\multicolumn{2}{|c|}{$\begin{array}{l}\text { IV. Instructional Neighborhoods } \\
\text { Places (wing(s) of the building) including spaces for teacher planning, flex zones } \\
\text { (places for multiple use), small and large group areas, wet areas for science and } \\
\text { art, hearth areas, and restrooms. The hearth area is a place used for reading and } \\
\text { quiet time. }\end{array}$}} \\
\hline & \\
\hline 28. Teacher Planning Areas** & Inadequate --- Ample \\
\hline 29. Flex Zones** & Poor --- Excellent \\
\hline 30. Small Group Areas & Inadequate --- Adequate \\
\hline 31. Large Group Areas & Inadequate --- Adequate \\
\hline 32. Wet Areas for Science ${ }^{* *}$ & Inadequate --- Adequate \\
\hline 33. Wet Areas for Art** & Inadequate --- Adequate \\
\hline 34. Hearth Areas & Poor --- Excellent \\
\hline 35. Activity Pockets** & Nonexistent --- Plentiful \\
\hline \multicolumn{2}{|l|}{ Spaces designed for small group work. } \\
\hline 36. Toilets in Classrooms ${ }^{* * *}$ & Percentage of classrooms \\
\hline (Percentage of classrooms having toilets: $0=0 \%, 1=10 \%, \ldots, 10=100 \%$ ) & having toilets \\
\hline 37. Storage** & None --- Ample \\
\hline \multicolumn{2}{|l|}{$\begin{array}{l}\text { Secured spaces for teachers and students to store their personal belongings, tools, } \\
\text { and supplies. }\end{array}$} \\
\hline 38. Classroom Walls** & Inadequate --- Adequate \\
\hline \multicolumn{2}{|l|}{ Walls are adequate/inadequate for displaying students' work. } \\
\hline 39. Inside Quiet Areas** & Inadequate --- Adequate \\
\hline \multicolumn{2}{|l|}{$\begin{array}{l}\text { Solitary places where students may go to pause and refresh themselves in } \\
\text { a quiet, supervisable setting. }\end{array}$} \\
\hline 40. Inside Private Spaces for Children & Inadequate --- Adequate \\
\hline \multicolumn{2}{|l|}{$\begin{array}{l}\text { Social, supervisable places where a small group of children may go to be alone } \\
\text { (i.e., reading areas, quiet places, reflection areas, listening areas, etc.). }\end{array}$} \\
\hline 41. Excitement** & Inhibits Learning--- \\
\hline Classrooms create an atmosphere of excitement for learning. & Promotes Learning \\
\hline 42. Technology** & Inhibits Learning--- \\
\hline $\begin{array}{l}\text { Computers and technology are placed within the learning environment in a } \\
\text { manner that complements teaching and learning. Technology appears as an } \\
\text { integral part of the curriculum. }\end{array}$ & Promotes Learning \\
\hline 43. Space & Close $\left(3.5^{\prime}-7^{\prime}\right)---$ \\
\hline General personal distance per student in classrooms and work areas. & $\operatorname{Far}\left(7^{\prime}-12^{\prime}\right)$ \\
\hline
\end{tabular}

Note. Instructions for completing the instrument: Please score design patterns on the scale $(0$ to 10$)$ as defined in each section. If the school does not have a specific feature, the score is 0 for that item. Design includes the way the schoolhouse is made, how it is arranged, and how the outside areas near the school complement the curriculum. The scale measures the degree to which each item is present in the learning environment. The following sample scale suggests a score of 9 , implying a stronger element. ${ }^{* *}$ Subscales remaining after reliability analysis (see Table 2 ). 
in schools are spaces that foster a sense of community or unity and belonging. These spaces are inviting and comfortable and include ample lighting. Examples of large group meeting places in schools include media centers, dining areas, places for casual student meetings (commons areas), amphitheaters, and auditoriums. This truncated review suggested five design classifications for large group meeting places that were included in the design assessment scale (see Items 18-22 in Table 1).

\section{Day Lighting and Views}

Harmful forms of lighting that exist in poorly designed schools are reason enough for educators to seriously consider the notion of wings of light (Alexander et al., 1977). Windows (with views) overlooking life provide another positive aspect of design amenable to transfer from the theories of pattern language to the school environment. Light is the most important environmental input, after food and water, in controlling bodily functions (Wurtman, 1975). Lights of different colors affect blood pressure, pulse, respiration rates, brain activity, and biorhythms. Full-spectrum light is required to influence the pineal gland's synthesis of melatonin, which in turn helps determine the body's output of the neurotransmitter serotonin, and it is critical to a child's health and development (Ott, 1973). To help reduce the imbalances caused by inadequate exposure to the near ultraviolet and infrared ends of the spectrum, full-spectrum bulbs that approximate the wavelengths provided by sunshine should replace standard fluorescent and tungsten bulbs (Hughes, 1980). There is ample evidence that people need daylight to regulate circadian rhythms (Alexander et al., 1977, p. 527). Poorly lit and windowless classrooms can cause students to experience a daily form of jet lag. Furthermore, forms of florescent lighting may affect some students and teachers by causing mild seizures.

The presence of natural light in classrooms has received attention from several researchers. In a study of more than 21,000 students, controlled for socioeconomic status, in California, Washington, and Colorado, the Heschong Mahone Group 
(1999) found that students with the most day lighting in their classrooms progressed 20\% faster on mathematics and $26 \%$ faster on reading tests over a period of one year than students having less daylight in their classrooms. Similarly, students in classrooms having larger window areas were found to progress $15 \%$ faster in mathematics and 23\% faster in reading than students in classrooms having smaller windows. Day lighting, provided from skylights, distinct from all the other attributes associated with windows, had a positive effect (p. 62).

Research published by Kuller and Lindsten (1992) suggested that windowless classrooms should be avoided for permanent use. They referenced medical doctors who reported a biological need for windows. Rather than being a distraction that disrupts the learning process, an argument often used from the conventional wisdom or best practices side, windows provide a necessary relief for students. This relief is associated with window gazing and is less consuming than the focused attention used to draw pictures or doodle in a notebook. It is much easier for students to refocus their attention back on the teacher when engaged in tasks requiring soft attention (such as window gazing) rather than those requiring more focused attention.

The significance of the light and color in the learning environment should be emphasized. Grangaard (1995) noted that light and color affect learning and blood pressure, specifying that off-task behavior decreased by $24 \%$ and blood pressure dropped by $9 \%$ when students were in a prescribed color and light setting as compared to a normal classroom. Sydoriak (1984) associated warm colors with slight elevations in blood pressure in children, while cooler colors caused slight drops in blood pressure. According to Nair and Fielding (2005), vistas of 50 feet or more are recommended to change focal length for eye health.

According to Edwards and Torcellini (2002), studies have shown that students in day lit rooms achieve higher test scores than students in windowless or poorly lit classrooms. Windows are the most common way of bringing natural light into the learning environment and invite the outdoors inside. Research indicates the following guidelines for window use: 
- Views from a school window should overlook some form of life.

- Unrestricted views to the outside are desirable.

- Views of other spaces from indoor and outdoor spaces (e.g., gardens, animals, fountains, mountains, people) should allow minds and eyes to take a break.

Adequacy of light for classrooms may entail:

- Skylights or borrowed light (natural, reflected light) from skylights. This feature is desirable for interior rooms without windows.

- Windows on two sides of every room, allowing an optimal mix of natural and artificial light.

\section{Instructional Neighborhoods}

An instructional neighborhood is a place that includes large group (approximately 20-30 students) and small group areas, spaces for student and teacher planning, wet areas for art, a hearth area, and toilets for the students and teachers. The instructional neighborhood should include windows for viewing outside the classroom and for bringing natural light inside. The ideal instructional neighborhood includes closed spaces to maximize flexibility and permits teachers and students to manage their own space. According to Weinstein (1979), there is considerable evidence that the classroom environment can affect nonachievement behaviors and attitudes. Soft classrooms have been associated with better attendance, greater participation, and more positive attitudes toward the class, the instructor, and classmates; minor design modifications introduced into already functioning classrooms have been shown to produce changes in student's spatial behavior, increased interaction with materials, and more substantive questioning (Weinstein, 1979, pp. 598-599). Adequacy of learning environment depends not only on square footage, but also on how the square footage is configured and organized with relation to other areas (Duke, 1998). 
After conducting extensive research, Moore and Lackney (1995) suggested that the classrooms of tomorrow would be similar to studios. There will be workstations and research space for each student. There also will be an assortment of spaces of various sizes. Common in schools will be central gathering places and presentation arenas. Workspaces for cooperative learning, quiet private areas, and nooks where students can think and work independently will be found in tomorrow's schools. Finally, teachers will have offices where they can do individual testing and counseling, organize individualized study programs, or telephone parents. Schools should be flexible enough to support a variety of changing instructional strategies. Folding partitions, large-group lecture rooms, small-group spaces, and staff offices are a few of the designs that are considered necessary.

Lomranz, Shapira, Choresh, and Gilat (1975) studied the amount of personal space children required. Measures of personal space were collected from 74 children aged 3, 5, and 7 years. A significant difference was discovered between the space needed by the 3-year-old and that of the 5- and 7-year-old children. The 3-year-olds needed significantly less personal space than the older children. According to Proshansky and Wolfe (1974), privacy has been shown to contribute to a child's growth and development. Although students like to withdraw, they do not like total seclusion. Based on this literature, a total of 16 design classifications for instructional neighborhoods were developed as part of the design assessment instrument.

\section{Method}

\section{Instrumentation Used to Define the Independent Variables}

Four sections of a larger instrument developed to provide a comprehensive and systematic method for assessing physical learning environments (Tanner \& Lackney, 2006, pp. 295-306) were employed in this study. This instrument, as summarized in Table 1, describes the independent variables in this study. It is 
based on a review of the literature and represents an accumulation of works related to specifying actual design items and their validity and reliability estimates. Over a period of several years, contributions to content validity were made to the development of the scale by Andersen (1999), Ayers, (1999), Tanner (1999, 2006), and Yarborough (2001).

Based on the Likert scale, the instrument contains items that may be scored from 0 to 10 , where 0 or blank indicates that the item is not present; thus a value from 0 to 10 may be assigned to a design item, depending on its quality and functionality, and the percentage of the item existing in the school being evaluated. Scores for each subsection are assumed to be additive. The instrument may be used to evaluate existing schools (postoccupancy evaluation), and of equal importance, it may be employed to influence new school design from the study of existing structures. It is intended for application only by people who have knowledge of the various items in its contents, and it is not intended for general distribution to accomplish data collection (i.e., a mail-out questionnaire).

\section{Reliability of the Instrument}

An item to scale analysis (Cronbach's alpha) was performed to determine the relationship between an individual item and the remainder of each subscale. Table 2 reveals the reliability coefficients for each of the four subscales employed in this study. The number of items was reduced from 43 to 21 based on the reliability analysis.

\section{The Instrumentation Used to Define the Dependent Variables}

Since 1935, the Iowa Tests of Basic Skills (ITBS) have helped to describe a student's developmental level, identify areas of relative strength and weakness in subject areas, and monitor yearto-year growth in the basic skills. The rationale for selecting the composite portion of the ITBS for this study was that a collection 


\section{Table 2}

\section{Reliability Analysis for the Subscales}

\begin{tabular}{lcccc}
\hline \multicolumn{1}{c}{ Category } & $\begin{array}{c}\text { Cronbach's } \\
\text { Alpha }\end{array}$ & $\begin{array}{c}\text { Cronbach's } \\
\text { Alpha } \\
\text { Standardized }\end{array}$ & $\begin{array}{c}n \text { of Selected } \\
\text { Items }\end{array}$ & $\begin{array}{c}n \text { of Original } \\
\text { Items }^{\mathrm{a}}\end{array}$ \\
\hline Movement and Circulation & .777 & .809 & 6 & 17 \\
Large Group Meeting Places & .711 & .704 & 3 & 5 \\
Day Lighting and Views & .823 & .823 & 4 & 5 \\
Instructional Neighborhoods & .736 & .720 & 8 & 16 \\
\hline
\end{tabular}

a These represent the original number of items based on the literature review for the four categories (see Table 1).

of tests in several subject areas, all of which have been standardized, makes it possible to issue research-based statements about a student's relative position on a standard scale. Without norms, there would be no basis for comparison. The ITBS norms allow one group of students to be compared with another group and schools to be compared with other schools. These comparisons provide the opportunity to examine the achievement levels of students in relation to a nationally representative student group.

\section{Data Collection}

Twenty-four rural elementary schools (K-6) in contiguous districts were included in the sample. The sample area was located in the west-central geographic region of Georgia in the United States. The study region included six counties serving approximately 11,500 students.

School design information as found in Table 1 was observed during site visits requiring approximately 2 hours each. The purpose of each visit was to complete a guided tour of the educational facilities and outdoor learning environments. The comprehensive tour was necessary to accurately complete the design assessment instrument for each facility. Only one researcher trained in school design and assessment conducted each site visit. That same researcher completed the instrument for each facility within one 
hour of concluding the visit and before beginning assessment of another school. All of the site visits were completed before the ITBS data were obtained from the Georgia Public Education Report Card for Parents (Georgia Department of Education, 1999), because having no knowledge of student performance reduced the chance of biasing the rater. The data bank for this study included the following variables: achievement data (average composite third-grade ITBS scores per school), number of students representing various ethnic groups, the average length of teaching experience of teachers and their levels of training, the number of gifted students, and a proxy for socioeconomic status (percentage of students receiving free and reduced cost school lunch; SES).

\section{Research Question and Assumptions}

The primary question for this study was: Does the school's physical environment influence third-grade students' composite ITBS scores? In order to seek a scientific answer to this question, correlations and reduced regression models were employed to describe student achievement (the dependent variable) with the four well-defined design variable sets representing the physical environment (independent variables). Under the hypothesis that places where students learn make a difference in what and how much they learn, several assumptions guided the study:

\section{General Assumptions}

- The school's physical environment may be classified according to sets of design patterns that are measurable on a Likert scale in terms of the degree of relative function and quality.

- Evidence of validity and reliability can be established for an instrument that measures the functionality, quality, and percentage of a certain design pattern's existence in a given school setting.

- Individuals who have thorough knowledge of the design patterns included in the instrumentation can accom- 
plish a valid and reliable evaluation of school learning environments.

- The Iowa Tests of Basic Skills are a valid and reliable measure of cognitive learning.

- This study was classified as nonexperimental, raising a concern for the explanatory variables. We already know that socioeconomic status accounts for the majority of the variance in student achievement studies; therefore, it may be difficult to document additional variance representing the physical environment. However, explaining even small amounts of additional variance would have important implications for school design.

\section{Statistical Assumptions}

- This descriptive study has been conducted under the assumption that the data were amenable to the correlation model. (To speculate beyond the sample and satisfy the statistical purist, 100 schools would have been appropriate for the regression analysis. Inference was not made regarding findings from the regression model).

- Both $r$ and $r^{2}$ enter regression calculations, and $r^{2}$ is a meaningful term indicating the proportion of variance in the test scores accounted for by the design variables in this study.

- Regression analysis, used in this study as the least squares fitting procedure, is an appropriate descriptive technique assuming: Errors have an expected value of zero, meaning on the average, errors balance out; independent variables are not random; uncontrolled variables are homoscedastic, or the same for each observation; uncontrolled variables are not autocorrelated; and the design variables are linearly independent.

- The descriptive regression technique can determine relationships between academic achievement and the physical environment, thereby possibly explaining the effect size (the influence of the physical environment on student achievement). Although the effect size does not 
ensure causality, repeated studies yielding similar effects can inform this elusive relationship.

- Overall, the regression analysis applied in this study is robust in the presence of departures from assumptions, except for measurement errors and specification errors.

\section{Analysis of Results}

An appropriate descriptive model was selected from variables that included a proxy for socioeconomic status (FREELUNCH) of the students, number of years of teachers' experience, teachers' levels of formal education (T5-Master's Degree, T6-Master's Plus One year, and T7-Doctorate), and percentage of White students and gifted students as defined by state regulations. Data on the cost of school construction per unit, complicated by poor record keeping and adjustments for inflation, were unavailable. Table 3 reveals that the proxy for SES (FREELUNCH) was a suitable control, $F=9.59, p=.007$. None of the other control variables were statistically significant.

The dependent variable (third-grade composite ITBS) had a mean score of 49.4583 and a standard deviation of 13.34811 for the 24 schools. Table 4 indicates that the control variable (SES = percentage of students on free and reduced cost for a school lunch) explained over $47 \%$ of the variance in the ITBS, $R^{2}=$ $.472 ; F(1,22)=19.631, p<.001$. The multiple correlation $(R=$ .687) was large and statistically significantly different from zero. This served as the reduced regression for the remainder of the analysis.

Next, the four subsets of design variables were added, each independently, to the reduced regression equation in Table 4. The results (Table 5) indicated, for example, that for Movement and Circulation the $R^{2}$ increased from .472 to .541 .

Analyses for each of full and reduced regressions are shown in Table 6. Each effect is the difference between the full and reduced regression. Each of the four full regression models, which included subsets of the design elements, explained between $2 \%$ 


\section{Table 3}

Selecting the Model

\begin{tabular}{lcrrrc}
\hline \multicolumn{1}{c}{ Source } & Type III Sums of & \multicolumn{2}{c}{ Mean } \\
& \multicolumn{1}{c}{ Squares } & $d f$ & \multicolumn{1}{c}{ Square } & \multicolumn{1}{c}{$F$} & \multicolumn{1}{c}{$p$} \\
\hline Corrected Model & $2656.257 \mathrm{a}, \mathrm{b}$ & 7 & 379.465 & 4.211 & .008 \\
Intercept & 1029.763 & 1 & 1029.763 & 11.428 & .004 \\
FREELUNCH & 864.141 & 1 & 864.141 & 9.590 & .007 \\
AVEXPERIENCE & 101.682 & 1 & 101.682 & 1.128 & .304 \\
T5-Master's & 0.662 & 1 & 0.662 & 0.007 & .933 \\
T6-Master's + & 38.006 & 1 & 38.006 & 0.422 & .525 \\
T7-Doctorate & 5.448 & 1 & 5.448 & 0.060 & .809 \\
PCTWHITE & 264.450 & 1 & 264.450 & 2.935 & .106 \\
GIFTED & 4.676 & 1 & 4.676 & 0.052 & .823 \\
Error & 1441.701 & 16 & 90.106 & & \\
Total & 62805.000 & 24 & & & \\
Corrected Total & 4097.958 & 23 & & & \\
\hline
\end{tabular}

${ }^{\mathrm{a}}$ Computed using alpha $=.05 .{ }^{\mathrm{b}} R$ Squared $=.648($ Adjusted $R$ Squared $=.494)$.

\section{Table 4}

\section{Reduced Regression}

\begin{tabular}{|c|c|c|c|c|c|}
\hline \multicolumn{6}{|c|}{ Model Summary } \\
\hline$R$ & $R^{2}$ & & Adjusted $R^{2}$ & $\begin{array}{r}\text { Standa } \\
\text { Es }\end{array}$ & $\begin{array}{l}\text { Error of } \\
\text { ate }\end{array}$ \\
\hline .687 & .472 & & .448 & & \\
\hline \multicolumn{6}{|c|}{ ANOVA $^{b}$} \\
\hline & Sum of Squares & $d f$ & Mean Squares & $F$ & sig. \\
\hline Regression & 1932.371 & 1 & 1932.371 & 19.631 & $<0.001$ \\
\hline Residual & 2165.588 & 22 & 98.436 & & \\
\hline Total & 4097.958 & 23 & & & \\
\hline
\end{tabular}

a $($ Constant $)$, SES $\left(\right.$ FREELUNCH $=$ proxy for SES). ${ }^{\mathrm{b}}$ Dependent Variable: Third-Grade ITBS Composite. 


\section{Table 5}

Regression for the Design Set:

Dependent Variable $=$ Third-Grade Composite ITBS

\begin{tabular}{|c|c|c|c|c|c|c|}
\hline & \multicolumn{6}{|c|}{ Summary } \\
\hline & Model & $R$ & $R$ & \multicolumn{2}{|c|}{ Adjusted $R$ Square } & $\begin{array}{l}\text { Standard } \\
\text { Error of the } \\
\text { Estimate }\end{array}$ \\
\hline & 1 & $.735^{\mathrm{a}}$ & .541 & \multicolumn{2}{|c|}{.497} & 9.466 \\
\hline & 2 & $.700^{\mathrm{b}}$ & .490 & \multicolumn{2}{|c|}{.441} & 9.979 \\
\hline & 3 & $.705^{c}$ & .497 & \multicolumn{2}{|c|}{.449} & 9.908 \\
\hline & 4 & $.709^{d}$ & .503 & \multicolumn{2}{|c|}{.455} & 9.852 \\
\hline \multicolumn{7}{|c|}{ ANOVA } \\
\hline \multirow{4}{*}{1} & Model & $\begin{array}{l}\text { Sum of } \\
\text { Squares }\end{array}$ & $d f$ & Mean Square & $F$ & sig. \\
\hline & Regular & 2216.432 & 2 & 1108.216 & 12.369 & $<0.001$ \\
\hline & Residual & 1881.526 & 21 & 89.596 & & \\
\hline & Total & 4097.958 & 23 & & & \\
\hline \multirow[t]{3}{*}{2} & Regular & 2006.674 & 2 & 1003.337 & 10.075 & .001 \\
\hline & Residual & 2091.285 & 21 & 99.585 & & \\
\hline & Total & 4097.958 & 23 & & & \\
\hline \multirow[t]{3}{*}{3} & Regular & 2036.326 & 2 & 1018.163 & 10.371 & .001 \\
\hline & Residual & 2061.632 & 21 & 98.173 & & \\
\hline & Total & 4097.958 & 23 & & & \\
\hline \multirow[t]{3}{*}{4} & Regular & 2059.680 & 2 & 1029.840 & 10.610 & .001 \\
\hline & Residual & 2038.278 & 21 & 97.061 & & \\
\hline & Total & 4097.958 & 23 & & & \\
\hline
\end{tabular}

a Predictors: (Constant), Movement and Circulation, SES-Model 1. b Predictors: (Constant), Large Group Meeting Places, SES-Model 2. ${ }^{\circ}$ Predictors: (Constant), Day Lighting and Views, SES-Model 3. 'Predictors: (Constant), Instructional Neighborhoods, SES-Model 4.

and $7 \%$ of additional variance in achievement when compared to the reduced model, which included a measure of school SES. The composite relationship of the design variables (the sum of the independent subscales) to achievement was $r=.543, p<$ 0.001 , as shown in Table 7. 


\section{Table 6}

The Effects of School Design Variables

on Student Achievement

\begin{tabular}{lccc}
\hline \multicolumn{1}{c}{ Full } \\
Design Variable Set & $\begin{array}{c}\text { Regression } \\
R^{2 a}\end{array}$ & $\begin{array}{c}\text { Reduced } \\
\text { Regression } R^{2}\end{array}$ & Effect \\
\hline Movement and Circulation & .541 & .472 & 0.069 \\
Large Group Meeting Places & .490 & .472 & 0.018 \\
Day Lighting and Views & .497 & .472 & 0.025 \\
Instructional Neighborhoods & .503 & .472 & 0.031 \\
\hline
\end{tabular}

${ }^{\text {a }}$ Each $R^{2}$ was significant at the .01 level.

\section{Table 7}

The Relationship Among Composite ITBS Scores, Total Design Scores, and SES

\begin{tabular}{|c|c|c|c|}
\hline \multicolumn{4}{|c|}{ Descriptive Statistics } \\
\hline & & Standard & \\
\hline & Mean & Deviation & $n$ \\
\hline ITBS Composite & 49.458 & 13.348 & 24 \\
\hline SES & 53.850 & 19.098 & 24 \\
\hline Total Design Score & 93.292 & 27.109 & 24 \\
\hline \multicolumn{4}{|c|}{ Pearson Correlations } \\
\hline & ITBS & SES & $\begin{array}{c}\text { Total Design } \\
\text { Score }\end{array}$ \\
\hline ITBS Composite & 1.00 & & \\
\hline SES & $-.687^{* *}$ & 1.00 & \\
\hline Total Design Score & $.543^{* *}$ & $-.457^{*}$ & 1.00 \\
\hline
\end{tabular}

Causality cannot be established in this descriptive study and inference is not recommended. However as a guide to additional research in this area, note that in Table 7 , the relationship between the percentage of free and reduced lunch students and third-grade achievement was negative, $r=-.687$. As the percent- 
age of students receiving school lunch at free and reduced cost increased, the achievement level decreased. On the other hand, as the school design score increased, so did student achievement, $r=.543, p=0.006$. After controlling for school SES, each of the four elements resulted in a small but statistically significant increase in $R^{2}$, indicating that the design elements do explain some unique variance in school achievement, over and above that which is explained by school SES.

\section{Discussion}

From this descriptive, nonexperimental study, no attempt was made to predict future ITBS scores based on school design. The study was initiated with the uncertainty of the presence of significant relationships among the school design variables and student achievement. Given the finding that the effect size was positive in each case and that the total effect of the school design variables correlated positively $(r=.543, p=0.006)$ with student achievement, it is clear that the design variables do correlate with achievement, and that these four school design variables had positive relationship with student outcomes in these 24 elementary schools.

Some uncertainties remain; this type of observational study cannot determine a causal relationship. It only indicates an association between the presence of certain design patterns and student achievement. This study did not measure school funding, a variable that might explain the observed relationship between the physical environment and academic achievement. In addition, teaching ability might be better in some schools than others. The training and experience measures did not measure teaching ability, although they might have approximated it. Should the study be replicated, in addition to the variables used here, cost factors should be considered at each site. These data were unavailable for this study. 


\section{Implications}

What lesson from these findings is there for teachers, educational decision-makers, planners, architects, school boards, and educational policy makers? The question remains as to whether there was a correlation between teaching ability and the teachers' assignment to certain spaces. For example, in the widely published study of daylight and student learning, a concern arose regarding teachers with more seniority or experience being assigned to classrooms with more daylight and windows. "It might be a function of teachers in day lit classrooms being more motivated or alert or responsive to students" (Heschong Mahone Group, 1999, p. 58).

As a small group of researchers struggle with academia to draw attention to the sociophysical learning environments in education, it is hypothesized that the evidence from this study, if supported by similar studies, may point to the importance of the opportunity for students to move freely within and around the school facility. One logical hypothesis would be that overcrowding is harmful to students (see Weinstein, 1979).

Currently, teachers are rarely exposed to information or literature in their formal training that ties the sociophysical learning environment to student achievement. Even in schools where windows are available to allow natural light into the classroom, it is not uncommon to find blinds pulled or other obstructions that prevent views to the outside and daylight from entering. The findings in this study supporting "day lighting and views" are verified by another study. For example, "Students in classrooms with the most day lighting were found to have $7 \%$ to $18 \%$ higher scores than those with the least" (Heschong Mahone Group, 1999 , p. 3). There are strong implications from this finding.

Given the guarded findings in this study, parallel studies might be conducted on the school's physical environment to validate best practices claims. Will the creation of views from school windows that overlook some form of life, unrestricted views, views that allow minds and eyes to take a break, borrowed light in interior classrooms, and installation of windows on two 
sides of every room to allow an optimal mix of natural and artificial light improve student learning?

Speculation regarding the design patterns (variables) in this study, and the other design patterns that were excluded because constraints of reliability coefficients in this data set were not met, may generate questions regarding exactly how much that teachers, architects, planners, and administrators should know about the influence of the physical environment on student outcomes. Perhaps interest in further research in this neglected area of educational research may be sparked. Before we can predict student achievement from school design variables, with the four subgroups of predictors found in this study, the sample must include approximately 100 schools. Future experimental research also could shed some light on the impact of design elements on student achievement. This will be a challenging, costly, and timeconsuming effort; but it may be highly rewarding if one accepts the hypothesis that the school's physical environment may affect student outcomes.

\section{References}

Alexander, C. (1979). The timeless way of building. New York: Oxford University Press.

Alexander, C., Ishikawa, S., \& Silverstein, M. (1977). A pattern language. New York: Oxford University Press.

Andersen, S. (1999). The relationship between school design variables and scores on the Iowa Test of Basic Skills. Unpublished doctoral dissertation, University of Georgia, Athens.

Ayers, P. D. (1999). Exploring the relationship between high school facilities and achievement of high school students in Georgia. Unpublished doctoral dissertation, University of Georgia, Athens.

Banghart, F. W., \& Trull, Albert, Jr. (1973). Educational planning. New York: Macmillan.

Castaldi, B. (1994). Educational facilities: Planning, modernization and management (4th ed.). Boston: Allyn \& Bacon.

Cochran, C. D., Hale, D., \&Hissam, C. (1984). Personal space requirements in indoor versus outdoor locations. Journal of Psychology, 117, 121-123. 
Colven, R. (1990). The quality of the physical environment of the school and the quality of education: Conclusions of a seminar. (ERIC Document Reproduction Service No. ED324791)

Crumpacker, S. S. (1995). Using cultural information to create schools that work. In A. Meek (Ed.), Designing places for learning (pp. 31-42). Alexandria, VA: Association for Supervision and Curriculum Development.

Duke, D. L. (1998). Does it matter where out children learn? (ERIC Document Reproduction Service No. ED418578)

Duncanson, E. (2003). Classroom space: Right for adults but wrong for kids. Educational Facility Planner, 38, 24-28.

Earthman, G. I., \& Lemasters, L. K. (1998). Where children learn: $A$ discussion of how a facility affects learning. (ERIC Document Reproduction Service No. ED419368)

Edwards, L., \& Torcellini, P. (2002). A literature review of the effects of natural light on building occupants (Tech. Rep. No. NREL/ TP-550-30769). Golden, CO: National Renewable Energy Laboratory.

Georgia Department of Education.(1999). School reportcards. Retrieved September 20, 2006, from http://www.doe.k12.ga.us

Grangaard, E. M. (1995). Color and light effects on learning. (ERIC Document Reproduction Service No. ED382381)

Hall, E. (1959). The silent language. New York: Anchor Books.

Heschong Mahone Group. (1999). Day lighting in schools. Fair Oaks, CA: Author.

Hughes, P. C. (1980). The use of light and color in health. In A. C. Hastings, J. Fadiman, \& J. S. Gordon (Eds.), Health for the whole person: The complete guide to holistic medicine (pp. 71-83). Boulder, CO: Westview Press.

Kuller, R., \& Lindsten, C. (1992). Health and behavior of children in classrooms with and without windows. Journal of Environmental Psychology, 12, 305-317.

Lemasters, L. K. (1997). A synthesis of studies pertaining to facilities, student achievement, and student behavior. (ERIC Document Reproduction Service No. ED447678)

Lomranz, J., Shapira, A., Choresh, N., \& Gilat, Y. (1975). Children's personal space as a function of age and sex. Developmental Psychology, 11, 541-545.

Moore, G. T., \& Lackney, J. A. (1995). Design patterns for American schools: Responding to the reform movement. In A. Meek 
(Ed.), Designing places for learning (pp. 11-22). Alexandria, VA: Association for Supervision and Curriculum Development.

Montessori, M. (1967). The absorbent mind. New York: Holt, Rinehart and Winston.

Nair, P., \& Fielding, R. (2005). The language of school design: Design patterns for 21st Century schools. Minneapolis, MN: Design Share.

National Center for Education Statistics. (2000). Condition of America's public school facilities: 1999 (NCES 2000-032). Washington, DC: U.S. Department of Education.

National Center for Education Statistics. (2003). Planning guide for maintaining school facilities. Washington, DC: U.S. Department of Education. Retrieved November 1, 2007, from http://nces.ed.gov/ pubs2003/maintenance

National Center for Education Statistics. (2007). Public school principals report on their school facilities (NCES 2007-007). Washington, DC: U.S. Department of Education. Retrieved November 1, 2007, from http://nces.ed.gov/pubsearch/pubsinfo.asp?pubid=2007007

Ott, J. (1973). Health and light. New York: Simon and Schuster.

Piaget, J. (1924). Judgment and reasoning in the child. New York: Harcourt Brace.

Proshansky, E., \& Wolfe, M. (1974). The physical setting and open education. School Review, 82, 557-574.

Simmel, G., Frisby, D., \& Featherstone, M. (1997). Simmel on culture: Selected writings. Thousand Oaks, CA: Sage.

Skinner, B. F. (1957). Verbal learning. New York: Appleton-CenturyCrofts.

Sommer, R. (1969). Personal space. Englewood Cliffs, NJ: PrenticeHall.

Sydoriak, D. E. (1984). An experiment to determine the effects of light and color in the learning environment. Unpublished doctoral dissertation, University of Arkansas, Little Rock.

Tanner, C. K. (1999, November). A school design assessment scale. Paper presented at the annual conference of the Council of Educational Facility Planners, International, Baltimore.

Tanner, C. K. (2000). The influence of school architecture on academic achievement. Journal of Educational Administration, 38, 309-330.

Tanner, C. K. (2006). Effects of the school's physical environment on student achievement. Educational Planning, 15(2), 25-44.

Tanner, C. K., \& Lackney, J. A. (2006). Educational facilities planning: Leadership, architecture, and management. Boston: Allyn \& Bacon. 
Watson, J. (1928). The ways of behaviorism. New York: Harper and Brothers.

Weinstein, C. S. (1979). The physical environment of the school: A review of the research. Review of Educational Research, 49, 577-610.

Wohlwill,J. F., \& van Vliet, W. (1985). Habitats for children: The impacts of density. Hillsdale, NJ: Lawrence Erlbaum Associates.

Wurtman, R.J.(1975). The effects of light on the human body. Scientific American, 233, 68-77.

Yarborough, K. A. (2001). The relationship of school design to academic achievement of elementary school children. Unpublished doctoral dissertation, University of Georgia, Athens.

\section{Author Note}

The data set for this study was collected by Dr. Kathleen Yarborough. Special thanks to her for her efficient work. Dr. Yarborough is an experienced elementary school teacher and administrator. She also holds a certificate in school design and planning. This research project was funded by a grant from the College of Education, the University of Georgia. No human subjects were used in this study. The unit of analysis was the schools mean test scores and design scores. The ITBS scores were public information. 